\title{
Reinoculação de bactérias diazotróficas aumentando o crescimento de plantas de trigo
}

\author{
Reinoculation of diazotrophic bacteria improving growth of wheat
}

\author{
Luiz Fernando Roesch ${ }^{1}$ Flávio de Oliveira Camargo ${ }^{2}$ \\ Pedro Alberto Selbach ${ }^{2}$ Enilson Saccol de Sá
}

\begin{abstract}
O presente estudo teve por objetivo avaliar o RESUMO suprimento de $N$ via FBN e a capacidade de isolados de bactérias diazotróficas, reinoculados em plantas de trigo, em promover o aumento do comprimento radicular. Foi feito um estudo sob condições controladas no qual avaliou a fixação biológica de nitrogênio e o aumento no comprimento radicular de plantas de trigo inoculadas com bactérias diazotróficas. Destacaram-se dois isolados testados pelo aumento de 2,3 vezes no comprimento radicular comparado aos tratamentos sem inoculação. Todos os isolados inoculados supriram a necessidade de $N$ das plantas de trigo até os 21 dias de desenvolvimento. Por meio desta técnica foi possível identificar isolados promissores para inoculação em plantas de trigo.
\end{abstract}

Palavras-chave: FBN; Promotores de crescimento de plantas.

\section{ABSTRACT}

With this work, we aimed evaluate the supply of $N$ from BNF and the ability of diazotrophic bacteria isolates, reinoculated in wheat plants, to enhancer root elongation. In this study, we access nitrogen fixation and root elongation of wheat plants by inoculation of diazotrophic bacteria under controlled conditions. Two tested isolates had been distinguished by enhanced 2.3 times root elongation than treatments without inoculation. All isolates can to supply nitrogen to the wheat plants until 21 days of development. By this study, we can to identify better isolates to inoculation in wheat plants.

Key words: BNF; Plant growth promotion.
Os custos econômicos e ambientais relacionados à fertilização nitrogenada têm estimulado a busca por alternativas que possam diminuir a utilização deste fertilizante sem que haja diminuição da produção. Uma das possibilidades é a inoculação de bactérias diazotróficas que podem associar-se a plantas de trigo para fixar nitrogênio atmosférico $\left(\mathrm{N}_{2}\right)$ (RONCATO-MACCARI et al., 2003) e,ou, produzir substâncias promotoras de crescimento de plantas (PCPs) (DOBBELAERE et al., 2003). Entretanto, os resultados de inoculação em gramíneas forrageiras e cereais nem sempre têm apresentado aumento da produção (OKON \& LABANDERA-GONZALEZ, 1994). Provavelmente, isto ocorra devido à linhagem da bactéria utilizada, à variação genética da cultivar e às condições ambientais que são fatores que interferem diretamente no sucesso da inoculação. SUMNER (1990) sugere que bactérias diazotróficas isoladas da mesma variedade da planta que se deseja inocular, são mais eficientes, especialmente quando a população nativa está presente. Organismos adaptados às condições ambientais da região podem apresentar melhores condições para concorrer com a microbiota nativa, tanto pela adaptação às condições edafoclimáticas, quanto pelo aumento populacional promovido pela inoculação. Aliado a isso, há

${ }^{1}$ Curso de Pós-graduação em Ciência do Solo da Universidade Federal do Rio Grande do Sul (UFRGS). Av. Bento Gonçalves, 7712, 91540-000. Porto Alegre, RS E-mail: luizroesch@via-rs.net. Autor para correspondência.

${ }^{2}$ Departamento de Ciência do Solo, UFRGS, Porto Alegre, RS, Brasil. 
necessidade de selecionar microrganismos promissores, capazes de fixar nitrogênio e produzir substâncias promotoras de crescimento de plantas (PCPs) para serem reinoculados na planta hospedeira. Deste modo, foi realizado o presente estudo com o objetivo de avaliar o suprimento de $\mathrm{N}$ via FBN e a capacidade de isolados de bactérias diazotróficas, reinoculados em plantas de trigo, em promover o aumento do comprimento radicular.

O estudo foi conduzido em condições controladas, por um período de 21 dias (temperatura de $25 \pm 1{ }^{\circ} \mathrm{C}$ com $10 \mathrm{~h}$ de luz e $14 \mathrm{~h}$ de escuro). As sementes de trigo foram desinfestadas superficialmente com uma solução de $\mathrm{NaOCl} 1 \%$ por 10 minutos e após este período, lavadas em água esterilizada. Posteriormente, as sementes foram pré-geminadas em placas de petri contendo algodão/água esterilizados. Após a germinação, as plântulas foram transferidas para tubos de ensaio (uma plântula por tubo) com capacidade de $150 \mathrm{~mL}$ contendo $40 \mathrm{~mL}$ de solução nutritiva (HOAGLAND,1950) esterilizada, agarizada (6 mM) em três repetições.

Para a obtenção do inóculo, colônias puras de bactérias diazotróficas foram isoladas de raízes desinfestadas, superficialmente, de plantas de trigo cultivadas a campo. $\mathrm{O}$ isolamento foi realizado segundo metodologia descrita por DÖBEREINER et al. (1995), utilizando o meio de enriquecimento $\mathrm{NFb}$ semi-sólido (utilizado para o isolamento de bactérias do gênero Azospirillum). As raízes desinfestadas superficialmente foram maceradas $(10 \mathrm{~g}$ de raízes para $90 \mathrm{~mL}$ de solução salina $-\mathrm{NaCl} 1 \%$ ) e diluídas serialmente até a diluição $10^{-5}$. Uma alíquota de $100 \mu \mathrm{L}$ da maior diluição foi inoculada em triplicata em meios de enriquecimento $\mathrm{NFb}$ semi-sólidos que foram incubados a $30^{\circ} \mathrm{C}$ até a formação de película característica (em forma de véu). Após esta etapa, parte da película foi transferida para placas de petri contendo o meio $\mathrm{NFb}$ sólido acrescido de $20 \mathrm{mg} \mathrm{L}^{-1}$ de extrato de levedura. As placas foram incubadas a $30^{\circ} \mathrm{C}$ até a formação de colônias isoladas. Para a purificação final, as colônias formadas foram novamente transferidas para meios de cultura semi-sólidos e, após a formação de película, transferidas para placas de petri contendo o meio Ágar-Batata (DÖBEREINER et al., 1995). Por meio deste procedimento, foram obtidos três isolados que foram utilizados para reinoculação em sementes de trigo (mesmo cultivar do qual foram obtidos os isolados), de acordo com os seguintes tratamentos: 1 - solução nutritiva + nitrogênio mineral (84 mM $\mathrm{NH}_{4} \mathrm{NO}_{3}$ ); 2 - solução nutritiva sem nitrogênio; 3 solução nutritiva inoculada com isolado $\mathrm{n}^{\circ} 1 ; 4$ solução nutritiva inoculada com isolado $n^{\circ} 2 ; 5$ - solução nutritiva inoculada com isolado $\mathrm{n}^{\circ} 3$.

Para a preparação do inóculo, os três isolados obtidos foram incubados em meio de cultura líquido ( $5 \mathrm{mM}$ de glicose, $10 \mathrm{mM}$ de peptona bacteriológica), com agitação (250rpm, por $24 \mathrm{~h}$ a $30^{\circ} \mathrm{C}$ ). Após a incubação, os meios de cultura foram submetidos à centrifugação (10 min a $3000 \mathrm{x} \mathrm{g})$ e o pelet foi ressuspendido em solução tampão fosfato $\left(0,4 \mathrm{~g} \mathrm{~L}^{-1}\right.$ de $\mathrm{KH}_{2} \mathrm{PO}_{4}, 1,48 \mathrm{~g} \mathrm{~L}^{-1}$ de $\mathrm{K}_{2} \mathrm{HPO}_{4}, 7,2 \mathrm{~g} \mathrm{~L}^{-1}$ $\mathrm{NaCl}, \mathrm{pH}$ 7) para preparação de um inóculo com a concentração bacteriana de $10^{6} \mathrm{UFC} \mathrm{mL}^{-1}$. Após o período de incubação, $1 \mathrm{~mL}$ da suspensão de células foi transferido para os tubos contendo a solução nutritiva. Os tratamentos 1 e 2, testemunha com nitrogênio e testemunha sem nitrogênio, respectivamente, foram inoculados com $1 \mathrm{~mL}$ da solução tampão esterilizada. Os resultados obtidos foram submetidos ao teste de comparação de médias de Tukey a 5\% de probabilidade de erro. Após 21 dias de crescimento, período em que as plantas do tratamento sem aplicação de nitrogênio demonstraram sintomas de deficiência de nitrogênio, as plantas foram colhidas e foi medido o comprimento das raízes, segundo TENNANT (1975), quantificado o nitrogênio total (TEDESCO et al., 1995) e o peso da matéria seca da parte aérea e das raízes.

As plantas de trigo inoculadas com bactérias diazotróficas tiveram seu comprimento radicular, conteúdo de nitrogênio e rendimento de matéria seca significativamente afetados nas condições do experimento (Tabela 1). $\mathrm{O}$ isolado $\mathrm{n}^{\circ} 1$ apresentou maior eficiência no aumento do comprimento radicular das plantas de trigo, com um incremento de 2,3 vezes em relação à média do comprimento das raízes medidas nos tratamentos sem inoculação e cerca de 1,3 vezes superior à média do comprimento medido no tratamento inoculado com o isolado $\mathrm{n}^{\circ} 3$ (Tabela 1 e Figura 1). Pode-se inferir, portanto, que o aumento no comprimento das raízes, observado neste estudo, pode ter ocorrido em conseqüência da produção de AIA pelos isolados testados, segundo KHALID et al. (2004), a produção de AIA em meio de cultura está positivamente correlacionada com o aumento radicular de plantas de trigo $(\mathrm{r}=0,99 * *)$ cultivadas em vasos.

Relacionando a fixação biológica do nitrogênio e o conteúdo de nitrogênio total das raízes e da parte aérea das plantas de trigo, observa-se que todos os isolados inoculados supriram a necessidade de $\mathrm{N}$ das plantas até os 21 dias de desenvolvimento. Tanto nas raízes quanto na parte aérea, o conteúdo de nitrogênio total das plantas inoculadas foi significativamente igual ao das plantas adubadas com nitrogênio (Tabela 1). Em média, o conteúdo de 
Tabela 1- Comprimento radicular, rendimento de matéria seca e conteúdo de nitrogênio total das raízes e da parte aérea de plântulas de trigo inoculadas com bactérias diazotróficas.

\begin{tabular}{|c|c|c|c|c|c|}
\hline \multirow{2}{*}{ Tratamentos } & \multirow{2}{*}{$\begin{array}{l}\text { Comprimento } \\
\text { radicular }\end{array}$} & \multicolumn{2}{|c|}{ Produção de matéria seca } & \multicolumn{2}{|c|}{ Conteúdo de $\mathrm{N}$ total } \\
\hline & & Raízes & Parte aérea & Raízes & Parte aérea \\
\hline & m planta ${ }^{-1}$ & \multicolumn{4}{|c|}{-------------------------- mg planta'1 ------------------------- } \\
\hline Com Nitrogênio & $21,33 \mathrm{~d}$ & $6 \mathrm{c}$ & $37 \mathrm{a}$ & $0,23 \mathrm{a}$ & $0,31 \mathrm{a}$ \\
\hline Sem nitrogênio & $25,76 \mathrm{c}$ & $11 \mathrm{ab}$ & $27 \mathrm{~b}$ & $0,13 \mathrm{~b}$ & $0,29 \mathrm{~b}$ \\
\hline Isolado $\mathrm{n}^{\mathrm{o}} 1$ & $54,36 \mathrm{a}$ & $18 \mathrm{a}$ & $34 \mathrm{a}$ & $0,22 \mathrm{a}$ & $0,33 \mathrm{a}$ \\
\hline Isolado $\mathrm{n}^{\mathrm{o}} 2$ & $52,14 \mathrm{a}$ & $18 \mathrm{a}$ & $25 \mathrm{~b}$ & $0,21 \mathrm{a}$ & $0,35 \mathrm{a}$ \\
\hline Isolado $\mathrm{n}^{\circ} 3$ & $40,37 \mathrm{~b}$ & $15 \mathrm{ab}$ & $28 \mathrm{~b}$ & $0,20 \mathrm{a}$ & $0,38 \mathrm{a}$ \\
\hline Média & 38,80 & 13,6 & 30,2 & 0,20 & 0,33 \\
\hline $\mathrm{CV}(\%)$ & 39 & 38 & 17 & 20 & 11 \\
\hline
\end{tabular}

Médias não seguidas pela mesma letra na coluna diferem estatisticamente pelo teste de Tukey, a 5\% de significância de erro.

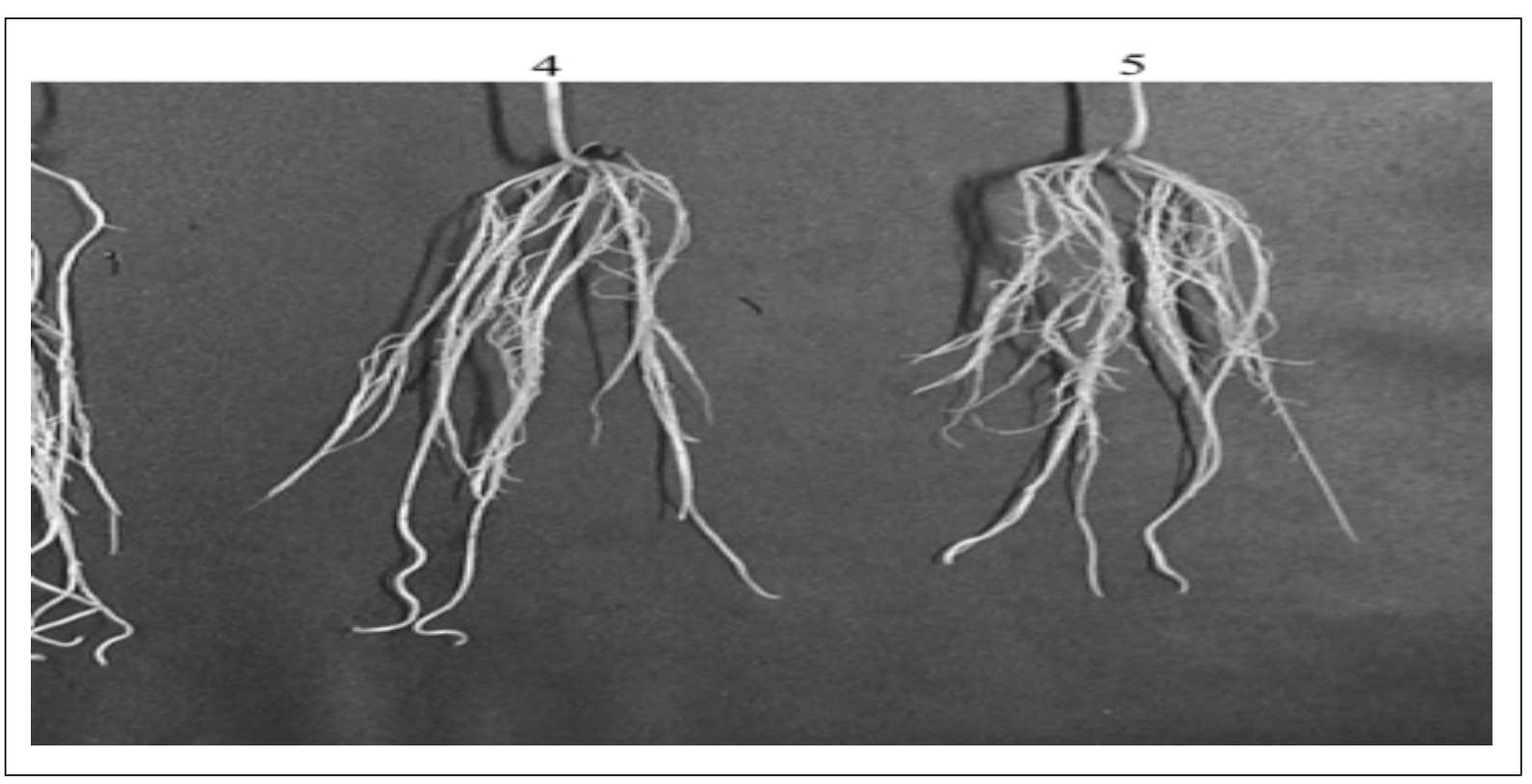

Figura 1 - Plantas de trigo, aos 21 dias após a germinação. 1- tratamento com adubação nitrogenada e sem inoculação; 2- tratamento sem adubação nitrogenada e sem inoculação; 3 - tratamento com inoculação do isolado $\mathrm{n}^{\circ} 1$; 4- tratamento com inoculação do isolado $\mathrm{n}^{\circ}$ 2; 5- tratamento com inoculação do isolado $n^{0} 3$.

nitrogênio total das raízes das plantas inoculadas foi de $0,21 \mathrm{mg}_{\text {planta }}{ }^{-1}$, sendo 1,6 vezes superior ao conteúdo de nitrogênio total das raízes das plantas controle, sem aplicação de $\mathrm{N}$ mineral. Com relação ao conteúdo de nitrogênio total da parte aérea, a média das plantas inoculadas foi de $0,35 \mathrm{mg} \mathrm{planta}^{-1}$, ou seja, 1,2 vezes superior a média das plantas do tratamento controle sem aplicação de $\mathrm{N}$ mineral.

Com relação ao acúmulo de matéria seca nas raízes, a análise estatística demonstrou similaridade entre os três tratamentos inoculados, entretanto, com relação ao rendimento da matéria seca da parte aérea, destacou-se o isolado $\mathrm{n}^{\mathrm{o}} 1$ (34 mg planta-1), que proporcionou acúmulo igual ao verificado no tratamento com aplicação de nitrogênio.

Os resultados obtidos permitem concluir que bactérias reinoculadas na planta hospedeira promoveram o aumento no comprimento radicular de plantas cultivadas in vitro e essas bactérias foram capazes de fixar $\mathrm{N}_{2}$ e transferi-lo para a planta, suprindo suas necessidades até os 21 dias após a germinação. Os isolados $\mathrm{n}^{\mathrm{o}} 1$ e 2 apresentaram maior eficiência no aumento do comprimento das raízes. Por 
meio desta técnica foi possível identificar dois isolados promissores para inoculação em plantas de trigo.

\section{REFERÊNCIAS}

DOBBELAERE, S. et al. Plant growth-promoting effects of diazotrophs in the rhizosphere. Critical Reviews in Plant Sciences, Amsterdam, v.22, n.2, p.107-149, 2003.

DÖBEREINER, J. et al. Como isolar e identificar bactérias diazotróficas de plantas não leguminosas. Brasília : Embrapa-SPI, 1995. 60p.

HOAGLAND, D.R.; ARNON, D.T. California agriculture experiment station. California, USA : University of Berkely, 1950. 32p. (Circular 347).

KHALID, A. et al. Screening plant growth-promoting rhizobacteria for improving growth and yield od wheat. Journal of Applied Microbiology, Oxford, v.96 p.473-480, 2004.
OKON, T.; LABANDERA-GONZALEZ, C. Agronomic applications of Azospirillum: an evaluation of 20 years worldwide field inoculation. Soil Biology Biochemistry, Oxford, v.26, n.12, p.1591-1601, 1994.

RONCATO-MACCARI, L.D.B. et al. Endophytic Herbaspirillum seropedicae expresses nif genes in gramineous plants. FEMS Microbiology Ecology, Amsterdam, v.45, p.39-47, 2003.

SUMNER, M.E. Crop responses to Azospirillum inoculation. Advances in Soil Sciences, New York, v.12, p.54-123, 1990.

TEDESCO, M.J. et al. Análise de solo, plantas e outros materiais. 2.ed. Porto Alegre : Universidade Federal do Rio Grande do Sul, 1995. 174p. (Boletim técnico, 5).

TENNANT, D.A. Test of modified line intersect method of estimating root lengt. Journal of Ecology, Oxford, v.63, p.995-1001, 1975. 